\title{
Correction to: Experimental and Numerical Study of a Geodesic Dome Under Static and Dynamic Loads and the Influence of Nodal Connections
}

\author{
D. Rossot ${ }^{1} \cdot$ R. D. Machado ${ }^{2} \cdot$ N. Barbieri ${ }^{1} \cdot$ K. F. de Lima ${ }^{1}$
}

Published online: 17 November 2021

(c) The Society for Experimental Mechanics, Inc 2021

\section{Correction to: Experimental Techniques}

https://doi.org/10.1007/s40799-021-00509-6

This article was updated to correct K. F. de Lima's name.

Publisher's Note Springer Nature remains neutral with regard to jurisdictional claims in published maps and institutional affiliations.

The online version of the original article can be found at https:// doi.org/10.1007/s40799-021-00509-6

\section{R. D. Machado}

rdm@ufpr.br

1 Department of Mechanical Engineering, PolytechnicSchool, Pontifical Catholic University of Paraná, Av.

Imaculada Conceição, 1155, Prado Velho, Curitba,

Paraná CEP 80-125-901, Brazil

2 CESEC - Civil Engineering Study Center, Centro Politécnico - Bairro Jardim das Américas, Federal University of Paraná,

Curitiba, PR, Brazil 